\title{
Enantioseparation of enilconazole using cyclodextrin-modified MEKC
}

\author{
Dadan Hermawan ${ }^{1,3 *}$, Ahmad Nor Shafiq Ahmad Kamali ${ }^{2}$, Wan Aini Wan Ibrahim ${ }^{1,2}$ and Mohd Marsin Sanagi ${ }^{1,2}$ \\ ${ }^{1}$ Ibnu Sina Institute for Fundamental Science Studies, Universiti Teknologi Malaysia, 81310 UTM Skudai, Johor, Malaysic \\ ${ }^{1}$ Department of Chemistry, Faculty of Science, Universiti Teknologi Malaysia, 81310 UTM Skudai, Johor, Malaysia \\ ${ }^{3}$ Department of Chemistry (MIPA), Faculty of Science and Engineering, Universitas Jenderal Soedirman, Purwokerto,Indonesia \\ Received 26 March 2011, Revised 10 April 2011, Accepted 10 May 2011, Available online 28 June 2011
}

\begin{abstract}
Enantiomeric separation of enilconazole has been successfully achieved using cyclodextrin modified micellar electrokinetic chromatography (CDMEKC) method with HP- $\gamma-\mathrm{CD}$ as chiral selector. Two parameters which were HP- $\gamma$-CD concentration and SDS concentration have been optimized by investigating their effects on resolution and analysis time. Enantioresolution of enilconazole was achieved by the optimized CD-MEKC system containing $40 \mathrm{mM} \mathrm{HP}-\gamma-\mathrm{CD}, 40 \mathrm{mM}$ SDS and $20 \mathrm{mM}$ phosphate buffer $(\mathrm{pH} 8)$ with resolution $(R \mathrm{~s}=1.3)$ and analysis time within 9 min. Good repeatabilities were obtained in term of $\mathrm{RSD} \%(n=3)$ for migration time, peak area and peak height ranging from 0.07 to $6.1 \%$. The optimized $\mathrm{CD}-$ MEKC method was a simple, less solvent used, and able to perform enantiomeric separation of enilconazole with a good resolution and relatively short analysis time.
\end{abstract}

| Enantioseparation | Enilconazole | CD-MEKC | HP- $\gamma$ - CD |

(B) 2011 Ibnu Sina Institute. All rights reserved. http://dx.doi.org/10.11113/mjfas.v7n1.241

\section{INTRODUCTION}

Chirality plays a major role in biological processes. Enantiomers of a bioactive molecule often have different biological effects. Their pharmacological activity may reside in only one enantiomer of a racemic mixture. In some cases, enantiomers may have qualitatively similar pharmacological activity, but different quantitative potencies, while in others one, enantiomer can be potentially toxic. Approximately $50 \%$ of marketed drugs are chiral, and of these approximately 50\% are mixture of enantiomers rather than single enantiomers [1]. Since drugs that are produced by chemically synthesis are usually a mixture of enantiomers, there is a need to quantify the level of the enantiomeric impurity.

Enilconazole has an asymmetrically substituted carbon atom therefore it has two stereoisomers. Enilconazole is one of the members in group of imidazole derivatives. Many imidazole derivatives are widely used or recommend for pharmaceutical used as antimycotics, antineoplastic agents, antiepileptics, thromboxane synthetase inhibitors and much more. This compound is also known as imazalil and used as systemic imidazole-like fungicide, frequently used as a post-harvest treatment to control a wide range of fungi on fruits, mainly citrus fruits, and vegetables [2].

Corresponding author at: Ibnu Sina Institute for Fundamental Science Studies, Universiti Teknologi Malaysia, 81310 UTM Skudai, Johor, Malaysia

E-mail addresses: dadan@ibnusina.utm.my (Dadan Hermawan)
Previously, study on enilconazole analysis has been reported [3-7]. However, many researchers focused on the qualitative and quantitative determination instead of enantiomeric separation. The chiral analysis is very important as stated by the US Food and Drug Administration for pharmaceutical, agrochemical and other chemical-based industries to specify the enantiomeric purity of the chiral compound [8]. It is thus of interest in the present study to developed a CD-MEKC methods for the enantioseparation of enilconazole using HP- $\gamma-\mathrm{CD}$ as the chiral selector.

\section{EXPERIMENTAL}

\subsection{Materials, method and instruments}

Stock solution of enilconazole $\left(2000 \mu \mathrm{g} \mathrm{mL} L^{-1}\right)$ was prepared by dissolving appropriate amount of methanol as solvent. Final dilutions were prepared by diluting the stock solution with methanol to $200 \mu \mathrm{g} \mathrm{mL} L^{-1}$. The separation solutions for CD-MEKC were prepared by dissolving appropriate amounts of SDS, CD, water, in phosphate buffer and adjusting the $\mathrm{pH}$ of the buffer with phosphoric acid solution. All the running buffer ware filtered through a $0.5 \mu \mathrm{m}$ nylon syringe filter from Whatman (California, $\mathrm{NJ}$, USA).

The capillary electrophoresis system was an Agilent capillary electrophoresis system (Agilent Technologies, 
Waldbronn, Germany), equipped with temperature control and diod array detection (DAD). Separation was performed using an untreated fused silica capillary of $64.5 \mathrm{~cm} \times 50 \mu \mathrm{m}$ i.d with an effective length of $56 \mathrm{~cm}$ to the detector window obtained from Polymicro Technologies (Phoenix, AZ, USA). Sample injection was performed electrokinetically for $3 \mathrm{kV}$ per $3 \mathrm{~s}$. The detection wavelength used was 200 $\mathrm{nm}$ and the capillary temperature was maintained at $25^{\circ} \mathrm{C}$. Data were collected and processed on computer using ChemStation software (Agilent Technologies). At the beginning of each day, the capillary was flush for 5 minutes with $1.0 \mathrm{~N} \mathrm{NaOH}$, followed by 2 minutes deionized water, then 3 minutes with $0.1 \mathrm{~N} \mathrm{NaOH}, 2$ minutes with deionized water and finally 10 minutes with running buffer. All sample injection was performed in triplicate.

\section{RESULTS \& DISCUSSION}

\subsection{Effect of HP- $\gamma-C D$ concentrations}

Effect of different HP- $\gamma$-CD concentrations was first explored to resolve the two enantiomers of enilconazole. The HP- $\gamma$-CD was varied in order to obtain the best separation of enilconazole using CD-MEKC. The HP- $\gamma-\mathrm{CD}$ concentration was varied in the concentration range 20 $50 \mathrm{mM}$ with $50 \mathrm{mM}$ SDS in $20 \mathrm{mM}$ phosphate buffer solution at $\mathrm{pH} 8.0$, the applied voltage $25 \mathrm{kV}$ and $25^{\circ} \mathrm{C}$. The typical result for the separation of enilconazole enantiomers using CD-MEKC with different HP- $\gamma$-CD concentrations is shown in Fig 1. It can be seen that there was no chiral resolution for enilconazole at $20 \mathrm{mM} \mathrm{HP}-\gamma-\mathrm{CD}$. While at 30 $\mathrm{mM}$ HP- $\gamma-\mathrm{CD}$, enilconazole enantiomers were only partially separated. Enantiomeric separation of enilconazole was successfully achieved when $40 \mathrm{mM}$ HP- $\gamma-\mathrm{CD}$ was employed. The resolution decreased when $50 \mathrm{mM} \mathrm{HP}-\gamma-\mathrm{CD}$ was used in the separation solution.

The migration time of enilconazole enantiomers were gradually shortened with increasing HP- $\gamma-\mathrm{CD}$ concentration. High concentration of HP- $\gamma-\mathrm{CD}$ increased the probability of analyte to include in its cavity. More enilconazole enantiomers will become incorporated in the HP- $\gamma$-CD phase as compared to the micelles phase. Since the HP- $\gamma$-CD moved at faster speed, thus the enantiomers will be transported quickly towards the detector and made the analysis time shortened.

The chiral recognition arise when the analyte make some interaction with HP- $\gamma$-CD. This interaction caused two labile diastable formed. The different in stability of the two diastereomers cause the mobility of the two enantiomers are differing. The two enantiomers will migrate at different velocity and will be detected by the detector at individual migration time. Thus, two peaks can be observed from the electropherogram. The best enantioresolution of enilconazole was obtained at $40 \mathrm{mM} \mathrm{HP}-\gamma-\mathrm{CD}$. At this concentration the best resolution $(R \mathrm{~s}=1.2)$ with analysis time within $9 \mathrm{~min}$ was obtained. Based on this data, optimum concentration of HP- $\gamma-\mathrm{CD}$ was set at $40 \mathrm{mM}$.

\subsection{Effect of SDS concentrations}

The effect of SDS concentration was then investigated, ranging from 30 to $50 \mathrm{mM}$. The typical result for the separation of enilconazole enantiomers using CD-MEKC with different SDS concentrations is shown in Fig 2. It was found that as the concentration of SDS was increased, the migration time also increased.

The increased in SDS concentration caused an increased in analysis time due to the increasing viscosity of the solution. Analyte will take a longer time to travel towards the detector because of higher viscosity. SDS is anionic micelles and supposes to move toward the positive electrode. However, due to the higher EOF as compared to the electrophoretic flows in the buffer solution, SDS was force to move towards negative electrode with retarded velocity. Thus, SDS will move slower than the buck solution. The higher concentration of SDS required longer time for EOF to attract analyte that accompanying with the SDS towards the detector window.

The resolution was increased with increasing SDS concentration. The effect of SDS concentration on enantioresolution of enilconazole can be explain by the retention factor, $k$. The higher the $k$ value, the higher resolution can be obtained. In MEKC, the $k$ value can be manipulating by adjusting the concentration of micelles and was given by the following equation [9]:

$$
k \approx \mathrm{Kv}(\mathrm{Csrf}-\mathrm{CMC})
$$

The above equation suggests that the capacity factor, $k$ is linearly dependent on the surfactant concentration. The relationship between SDS concentration and resolution described above was explained about the single peak appear in the electropherogram obtained. At concentration $30 \mathrm{mM}$, there was no enantioresolution observed at all. This observation probably due to the small concentration of SDS used and the concentration was not significant enough to separate the enilconazole enantiomers. The best enantioresolution of enilconazole enantiomers was obtained when $40 \mathrm{mM}$ SDS was employed. At this concentration the best resolution $(R \mathrm{~s}=1.3)$ with a short analysis time within 9 min was obtained. Based on this data, optimum concentration of SDS was set at $40 \mathrm{mM}$.

\subsection{Analytical performance of the CD-MEKC}

Performance of the optimized CD-MEKC was examined in terms of linearity, repeatability and LOD. The calibration curves were linear for the two stereoisomers of enilconazole $\left(r^{2}>0.980\right)$. Good repeatabilities in migration time, peak area and peak height were obtained in terms of RSD $\%$. The LOD obtained was $44-45 \mu \mathrm{g} \mathrm{mL}{ }^{-1}$. The linearity, repeatability and LOD of the optimized CDMEKC method are summarized in Table 1. 


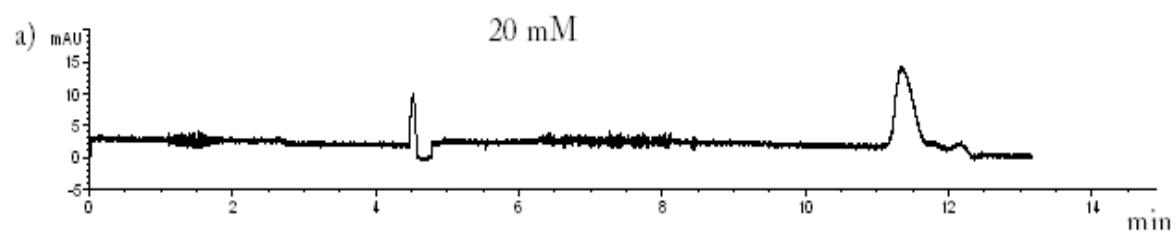

b)

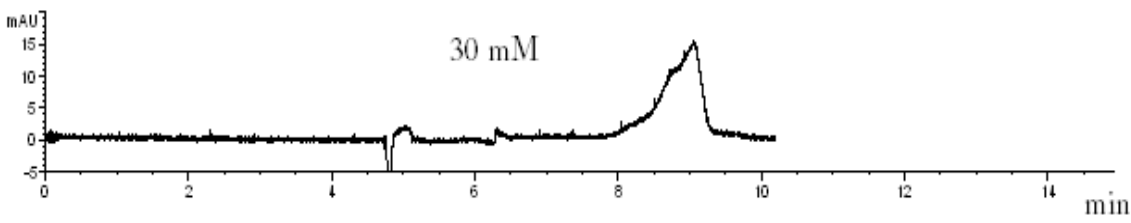

c)



d) mau

$50 \mathrm{mM}$

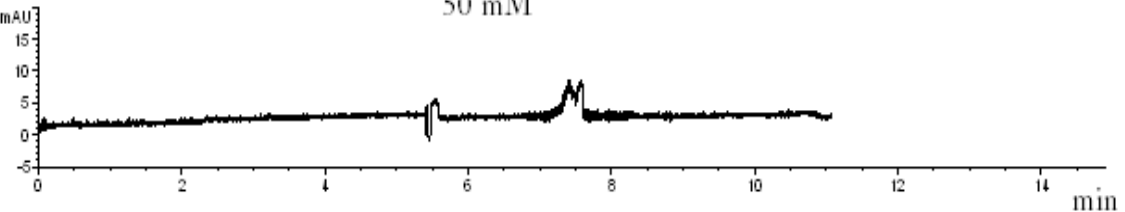

Figure 1: Enantioseparation of enilconazole using CD-MEKC with different HP- $\gamma$-CD concentration. separation solution: 20-50 mM HP$\gamma-\mathrm{CD}, 50 \mathrm{mM}$ SDS in $20 \mathrm{mM}$ phosphate buffer $(\mathrm{pH} 8)$; capillary, $64.5 \mathrm{~cm} \times 50 \mu \mathrm{m}$ I.D. (effective length, $56 \mathrm{~cm}$ ); applied voltage, $25 \mathrm{kV}$; temperature, $25^{\circ} \mathrm{C}$; sample injection, $3 \mathrm{kV}$ for $3 \mathrm{~s}$; sample, $200 \mu \mathrm{g} \mathrm{mL} \mathrm{L}^{-1}$ (in methanol).

a)



b)



c)



Figure 2: Enantioseparation of enilconazole using CD-MEKC with different SDS concentration. separation solution: 30 - $50 \mathrm{mM}$ SDS, $40 \mathrm{mM} \mathrm{HP}-\gamma-\mathrm{CD}$ in $20 \mathrm{mM}$ phosphate buffer ( $\mathrm{pH}$ 8); other conditions as in Fig 1. 
Table 1: Linearity, repeatability and LOD $(\mathrm{S} / \mathrm{N}=3)$ for enilconazole enantiomers in the optimized CD-MEKC

\begin{tabular}{lll}
\hline Parameters & Peak 1 & Peak 2 \\
\hline Concentration range & $50-200 \mu \mathrm{g} / \mathrm{mL}$ & $50-200 \mu \mathrm{g} / \mathrm{mL}$ \\
${ }^{1}$ Regression equation & $\mathrm{y}=0.590 \mathrm{x}-3.41$ & $\mathrm{y}=0.609 \mathrm{x}-4.435$ \\
$r^{2}$ & 0.981 & 0.983 \\
RSD \%(n $=3)$ & & \\
Migration time & 0.27 & 0.08 \\
Peak area & 0.07 & 2.1 \\
Peak height & 2.8 & 6.1 \\
LOD $(\mu \mathrm{g} / \mathrm{mL})$ & 44 & 45 \\
& & \\
\hline
\end{tabular}

${ }^{1}$ linearity range: $50-200 \mu \mathrm{g} \mathrm{mL}^{-1} ; \mathrm{y}=$ peak area, $\mathrm{x}=$ concentration $\left(\mu \mathrm{g} \mathrm{mL}^{-1}\right)$

\section{CONCLUSION}

In the present work, the optimization of HP- $\gamma-\mathrm{CD}$ concentration and SDS concentration were successfully developed for separation of enilconazole enantiomers. The mixture of $40 \mathrm{mM} \mathrm{HP}-\gamma-\mathrm{CD}, 40 \mathrm{mM}$ SDS, in $20 \mathrm{mM}$ phosphate buffer solution at $\mathrm{pH} 8.0$, applied voltage $25 \mathrm{kV}$ and temperature $25^{\circ} \mathrm{C}$ was able to separate the enilconazole enantiomers. The migration time was within 9 minutes and resolution obtained was 1.30. Good repeatabilities were obtained in term of RSD\% $(n=3)$ for migration time, peak area and peak height ranging from 0.07 to $6.1 \%$. However, the LOD obtained is quite high, $(44-45 \mu \mathrm{g} / \mathrm{mL})$. MEKC method usually suffers from low concentration sensitivity due to only small sample volume introduced and limited optical pathlenght for on-capillary photometric detection. Thus, some approach need to be employed together with MEKC to increase the concentration sensitivity. On-line preconcentration technique is seemed to be a good approach to recover the sensitivity problem suffers by MEKC technique. The present works can be used as the preliminary

study for the on-line preconcentration and chiral separation of enilconazole.

\section{ACKNOWLEDGEMENT}

The authors would like to thank Universiti Teknologi Malaysia for financial support through Institutional Research Vote No77547.

\section{REFERENCES}

[1] J. Mc Conathy,M. J. Owens, J. Clin Psychiatry. 5, 2003, 70-73.

[2] D. Ortelli, P. Edder, P., C. Corvi, Food Addit. Contam. 2005, 423-428.

[3] B.L. Chu, B.Y. Guo, Z. Peng, Z. Wang, G. Guo, J.M. Lin, J. Sep. Sci. 30, 2007, 923 - 929.

[4] N. Yoshioka, Y. Akiyama, K. Teranishi, J. Chromatogr. A.1022, 2004, 145-150.

[5] N. Yoshioka, Y. Akiyama, T. Matsuoka, T. Mitsuhashi, Food Control. 21, 2010, 212-216.

[6] B. Chankvatadze, G. Endresz, G. Blaschke, J. Chromatogr. A. 700, 1995, 43-49.

[7] E. Watanabe, Y. Yoshimura, Y. Yuasa, H. Nakazawa, Anal.Chim. Acta. 433, 2001, 199-206.

[8] FDA policy, Statement for the Development of New Stereoisomers Drugs, (1992), FDA, Rockville, MD.

[9] S. Fanali, M. Cristalli, R. Vespalec, P. Bocek, Chiral separation in capillary electrophoresis, (1994), New York: VCH. 